\title{
KAJIAN KONSEP KONTEKSTUAL BENTUK PADA BANGUNAN DI KAWASAN KOTA LAMA SEMARANG
}

\author{
Bella Mareta Thania ${ }^{1 *}$, Ari Widyati Purwantiasning ${ }^{2}$ \\ Program Studi Arsitektur, Universitas Muhammadiyah Jakarta1, \\ Program Studi Arsitektur, Universitas Muhammadiyah Jakarta ${ }^{2}$ \\ e-mail: *1bellamareta13@gmail.com, 2arwityas@yahoo.com
}

\begin{abstract}
Abstrak_ Desain yang kontekstual merupakan desain yang dapat diterima atau dikenali oleh masyarakat dan selaras atau harmoni dengan lingkungan sekitar. Namun kontekstualitas pada bangunan juga dapat mengenalkan bentuk baru yang selaras dengan lingkungan (dikenal dengan istilah kontras) dan desain bangunan yang sudah ada sebelumnya. Konsep kontekstual biasanya diterapkan pada kawasan-kawasan bersejarah dimana terdapat bangunan bersejarah yang masih dilestarikan. Salah satu kawasan bersejarah yang masih melestarikan nilai-nilai sejarah yaitu Kawasan Kota Lama Semarang. Bangunan sejarah yang ada pada Kawasan Kota Lama Semarang memiliki nilai sejarah yang tinggi. Hal ini karena, bangunan bersejarah yang ada menggambarkan pengaruh budaya lain pada Kawasan Kota Lama Semarang. Pada bangunan bersejarah, konsep kontekstual dapat dilihat dari motif desain bangunan, bentuk dasar bangunan, dan nilai sejarah. Konsep kontekstual bentuk memiliki dua prinsip yaitu kontras dan harmoni. Prinsip kontekstual bentuk bangunan sangat penting penerapannya pada suatu kawasan terutama kawasan bersejarah. Hal ini dapat mempertahankan identitas kawasan, khususnya Kawasan Kota Lama Semarang yang memiliki beragam bangunan. Metode deskriptif kualitatif merupakan metode yang digunakan dalam penelitian ini. Metode ini digunakan untuk menjelaskan secara deskriptif penerapan arsitektur kontekstual dalam segi bentuk bangunan melalui prinsip yang ada dengan mengetahui batasan kawasan dan jenis-jenis bangunan yang ada pada Kawasan Kota Lama Semarang. Hasil yang ingin dicapai dari penelitian ini adalah mengidentifikasi dan memberikan pemahaman mengenai prinsip-prinsip arsitektur kontekstual pada bentuk bangunan bersejarah di Kawasan Kota Lama Semarang.
\end{abstract}

Kata kunci : Kawasan Bersejarah; Kontekstual; Prinsip Kontekstual; Kota Lama Semarang.

\begin{abstract}
Contextual Concept is a design that can be accepted or recognized by the community and in harmony with the surrounding environment. However, contextuality in the building can introduce new forms that are in harmony with the environment (familiar with Contrast) and pre-existing building designs. Contextual Concept usually applies to the historical areas that still preserve historical values. One of the historical areas that still preserve historical values is Semarang Old City. Historical buildings that exist in Semarang Old City have a high historical value. It is because existing historic buildings illustrate the influence of other cultures in Semarang Old City. In the historical building, contextual concepts can be seen from the building design motifs, the basic form of the building, and historical value. The concept of contextual form has two principles, namely contrast, and harmony. The contextual principle of the building form is fundamental to be applied in historical areas. It can maintain the identity of the region, especially Semarang Old City which has a variety of buildings. The qualitative descriptive method was used in this study. This method was used to explain the application of contextual architecture descriptively in terms of building shapes through existing principles by knowing the boundaries of the area and types of buildings that exist in Semarang Old City. The results had been achieved from this study were to identify and provide an understanding of the contextual architectural principles of the shape of historic buildings in Semarang Old City.
\end{abstract}

Keywords: Historic District; Contextual; Contextual Principles; Semarang Old City.

\footnotetext{
${ }^{1}$ Program Studi Arsitektur, Universitas Muhammadiyah Jakarta

${ }^{2}$ Program Studi Arsitektur, Universitas Muhammadiyah Jakarta
} 


\section{PENDAHULUAN}

Arsitektur kontekstual merupakan suatu konsep dalam perancangan arsitektur, yang memperhatikan permasalahan visual antar bangunan dengan nuansa lingkungan yang ada di sekitarnya, dan studi terhadap keserasian antar bangunan yang berbeda gaya arsitektur dan berbeda zaman dalam lokasi yang berdekatan (Aldilla Indira, Wiwik Setyaningsih, 2018). Desain kontekstual merupakan desain yang dapat diterima atau dikenali oleh masyarakat dan selaras dengan lingkungan sekitar, namun dapat mengenalkan bentuk baru yang selaras dengan lingkungan dan desain bangunan yang sudah ada sebelumnya. Konsep kontekstual biasa diterapkan pada kawasan-kawasan bersejarah dimana terdapat bangunan bersejarah yang masih dilestarikan.

Penerapan arsitektur kontekstual dapat dilihat pada suatu kawasan, khususnya pada kawasan bersejarah. Wilayah pada suatu kota yang memiliki ciri khusus sehingga kawasan tersebut menjadi mudah dikenali merupakan penjelasan dari kawasan bersejarah. Kawasan bersejarah menjadi tempat dalam melakukan berbagai aktivitas karena merupakan kawaan yang dapat menjadi tempat rekreasi dan tempat mengeksplor suatu peninggalan sejarah yang selaras dengan lingkungan. (Purwantiasning, Masruroh, \& Nurhidayah, 2013). Bangunan-bangunan bersejarah di dalam sebuah kawasan bersejarah juga dapat menjadi kelekatan sejarah bagi seseorang individu yang memiliki memori akan bangunan atau kawasan bersejarah tersebut, seperti yang disampaikan oleh (Purwantiasning, AW.; Bahri, 2019) bahwa kelekatan sejarah akan membawa dampak emosional tertentu kepada setiap individu, dan tingkat emosionalnya juga akan berbeda-beda, karena keberadaan bangunan-bangunan bersejarah tersebut akan memberikan pengalaman individu yang berbeda-beda. Oleh karenanya kawasan bersejarah menjadi penting untuk diobservasi dalam penelitian ini dengan mengangkat bangunan-bangunan bersejarah yang ada di dalamnya.

Permasalahan visual bangunan dijelaskan dalam penelitian Rahayuningtyas (2016), Alsayyad (2001) mengatakan bahwa permasalahan visual yang selaras dengan lingkungan dapat diatasi dengan tiga cara. Pertama, dengan menggunakan sejarah lanskap menggunakan ikon pada suatu budaya, seperti gaya arsitektur, tipologi bangunan dan konfigurasi spasial. Kedua, memperkenalkan kembali citra pada suatu kawasan, berupa visual maupun suasana, dengan mengembalikan suasana asli daerah tersebut. Ketiga, memperbarui tempat-tempat yang memiliki sejarah atau tempat-tempat yang memiliki arti penting. Permasalahan yang ada pada suatu kawasan yaitu kurangnya keselarasan bentuk bangunan baru dengan bangunan yang sudah ada sebelumnya sehingga, membuat suatu kawasan kehilangan identitas dan tidak memiliki ciri khas.

Konsep arsitektur kontekstual bentuk biasanya diterapkan pada kawasan-kawasan bersejarah dimana terdapat bangunan bersejarah yang masih dilestarikan. Salah satu kawasan bersejarah yang masih dilestarikan adalah Kawasan Kota Lama Semarang. Kawasan ini memiliki nilai sejarah yang tinggi pada Kawasan Kota Lama Semarang dapat dilihat dari adanya berbagai bangunan bersejarah yang masih mempertahankan nilai-nilai sejarah dengan paduan pengaruh budaya lain pada suatu kawasan. Sehingga, pada Kawasan Kota Lama Semarang termasuk kawasan yang masih mempertahankan identitas sebagai kawasan bersejarah. Dalam penelitian Purwantiasning (2017), Hidayati (2009) menjelaskan bahwa yang termasuk dalam bangunan bersejarah adalah bangunan yang merupakan warisan budaya secara fisik atau dapat terlihat langsung nilai sejarahnya. 
Maka dari itu, penelitian ini memiliki tujuan menjelaskan penerapan konsep arsitektur kontekstual bentuk pada Kawasan Kota Lama Semarang. Selain itu, hal ini dapat menjadi acuan dalam mempertahankan bentuk pada bangunan yang ada di kawasan bersejarah dalam menjaga identitas suatu kawasan. Menurut Eunike Trifena Kolibu (2017) bahwa, "Penerapan prinsip kontekstual dibagi menjadi dua hal yaitu, kontras dalam segi bentuk dan harmoni dalam segi bentuk". hal ini dapat memperlihatkan keselarasan antara bangunna dengan lingkungan sekitar pada kawasan bersejarah.

\section{METODE}

Metode deskriptif kualitatif menjadi metode yang digunakan pada peneltian ini. Metode ini menggunakan observasi lapangan secara langsung untuk merekam beberapa titik pandang yang akan dianalisis yaitu dengan mengamati bangunan yang ada pada kawasan penelitian. Selain itu pengumpulan data dapat dilakukan dengan melakukan wawancara, melakukan studi pustaka dan dokumentasi. Penelitian ini, melakukan pemetaan bangunan pada empat sisi dengan penggambaran ulang secara skematik, mengidentifikasi bentuk bangunan sesuai dengan teori kontekstual bangunan dan melakukan perbandingan beberapa bangunan yang ada di Kawasan Kota Lama Semarang dengan melakukan analisis mengenai penerapan prinsip arsitektur kontekstual dalam segi bentuk. Penelitian ini membutuhkan waktu selama satu minggu yaitu pada tanggal 25 November 2019 sampai dengan 1 Desember 2019 dalam melakukan observasi langsung pada Kawasan Kota Lama Semarang. Batasan penelitian menggunakan data batasan kawasan bersejarah, tampak bangunan dan jenis bangunan di Kota Lama Semarang.

\section{HASIL DAN PEMBAHASAN}

\section{A. Deskripsi Kawasan}

Kawasan Kota Lama Semarang dahulunya merupakan pusat kota, dimana kawasan ini merupakan kawasan yang memiliki nilai sejarah yang tinggi. Kawasan Kota Lama Semarang merupakan kota jajahan Belanda. Hal ini, membuat kota Lama Semarang sering disebut Outstadt atau Little Netherland karena pada kawasan ini secara umum memiliki karakter bangunan bergaya Eropa. Kota Lama Semarang masih tetap terjaga karena adanya revitalisasi. Revitalisasi yang dilakukan merupakan kegiatan pemugaran pada bangunan bersejarah yang memberikan nilai tambah dalam segi ekonomi, sosial, dan budaya dalam pemanfaatan bangunan cagar budaya.

Kawasan Kota Lama Semarang juga merupakan kawasan permukiman. Hal ini dapat dilihat dari gaya arsitektur pada kawasan Kota Lama Semarang. Salah satu cara dalam melihat gaya arsitektur yaitu dengan memperhatikan tampak suatu bangunan. Beberapa tampak bangunan yang berada di Kawasan Kota Lama Semarang yaitu sebagai berikut. 


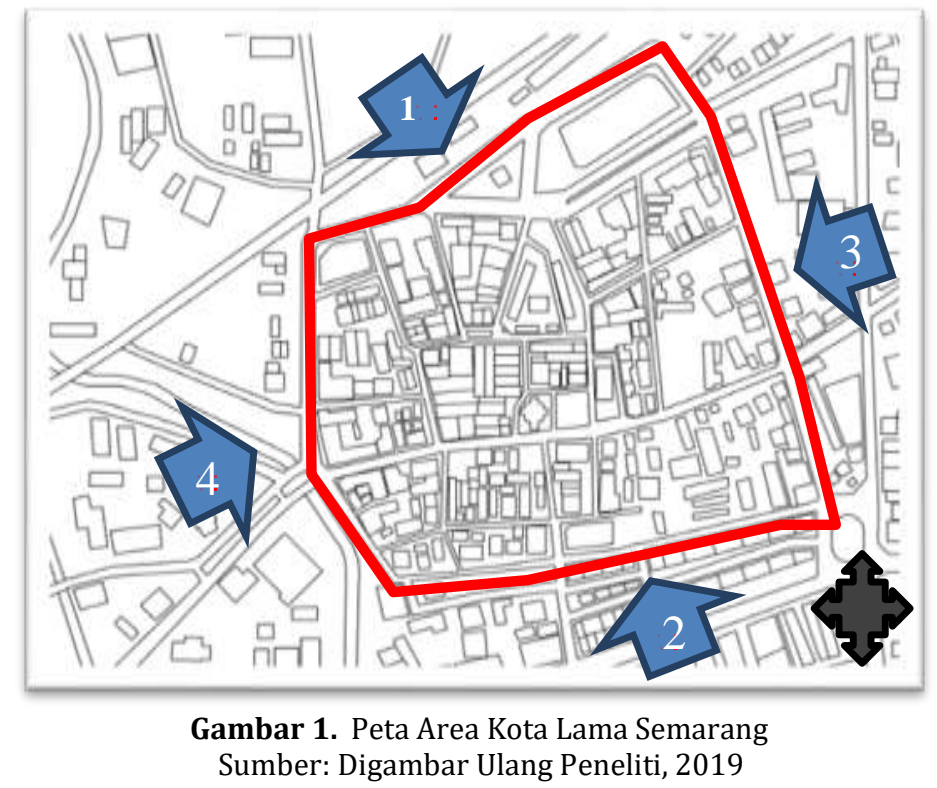

Hasil dan pembahasan pada penelitian Kajian Arsitektur Kontekstual Bentuk pada Bangunan di Kawasan Kota Lama Semarang yaitu memiliki fokus pada kontekstual bentuk bangunan-bangunan yang berada di kawasan bersejarah. Pembahasan sesuai dengan materi penelitian yang ada yaitu melihat kontekstual bentuk bangunan melalui prinsip-prinsip arsitektur kontekstual. Dalam arsitektur kontekstual memiliki dua nilai dalam pengelompokannya yaitu kontras dalam segi bentuk dan harmoni dalam segi bentuk.

\section{B. Dalam segi bentuk}

Arsitektur kontekstual memiliki beberapa ciri menurut Brolin dalam (Vini Asfarilla, Yohannes Firzal, n.d.) yang dapat dilihat dari bentuk bangunan dan lingkungan sekitarnya. Pada bangunan di Kota Lama Semarang memiliki beragam bentuk. Hal ini dapat dilihat dari bentuk atap bangunan dan elemen pembentuk tampak bangunan seperti elemen vertikal dan elemen horizontal yang digunakan sebagai pembentuk tampak bangunan di Kota Lama Semarang. Keberagaman bentuk yang ada dikarenakan adanya berbagai gaya arsitektur pada bangunan-bangunan di Kota Lama Semarang.

1. Tampak Kawasan 1 ( Jalan Tawang )

Pada tampak kawasan 1 (Gambar 2) terdapat bangunan fasilitas sosial yang ditandai dengan kotak berwarna kuning yaitu, bangunan Stasiun Tawang dan bangunan resort. Terdapat bangunan ruko yang ditandai dengan kotak berwarna merah. Selain itu, terdapat bangunan tua yang sudah tidak berfungsi ditandai dengan kotak berwarna hitam. Prinsip kontekstual bangunan yang ada pada tampak kawasan 1 yaitu kontras dalam segi bentuk. Dapat dilihat pada gambar bahwa ketiga jenis bangunan yang ada memiliki bentuk yang berbeda. 


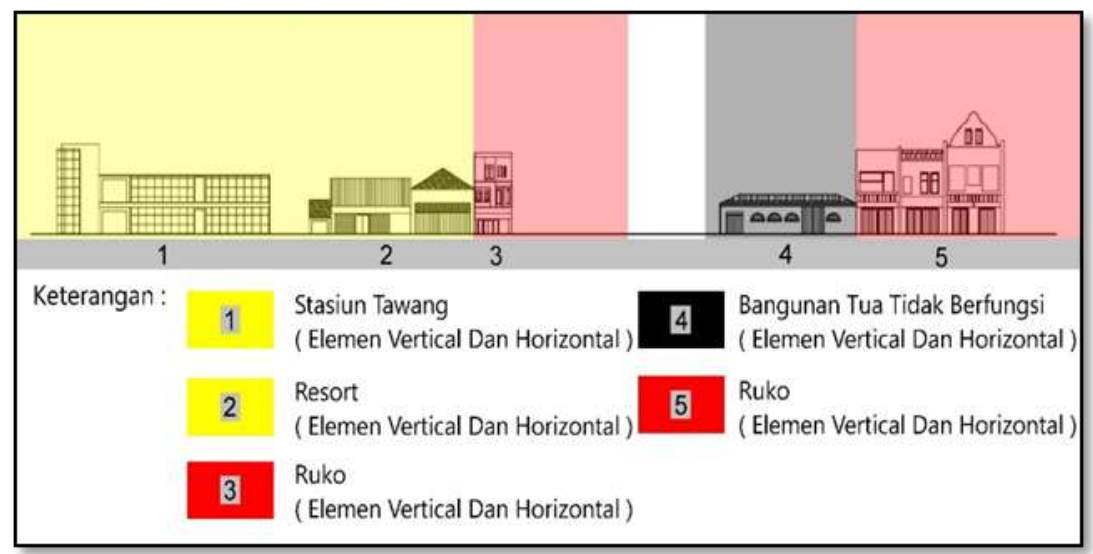

(a) Tampak Kawasan 1

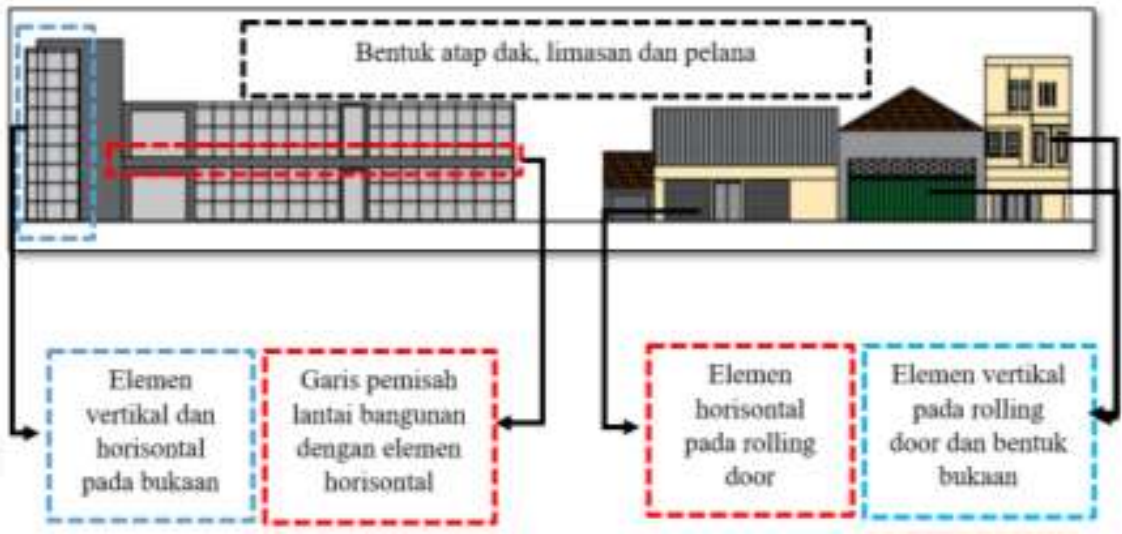

(b) Bentuk Bangunan Kawasan 1

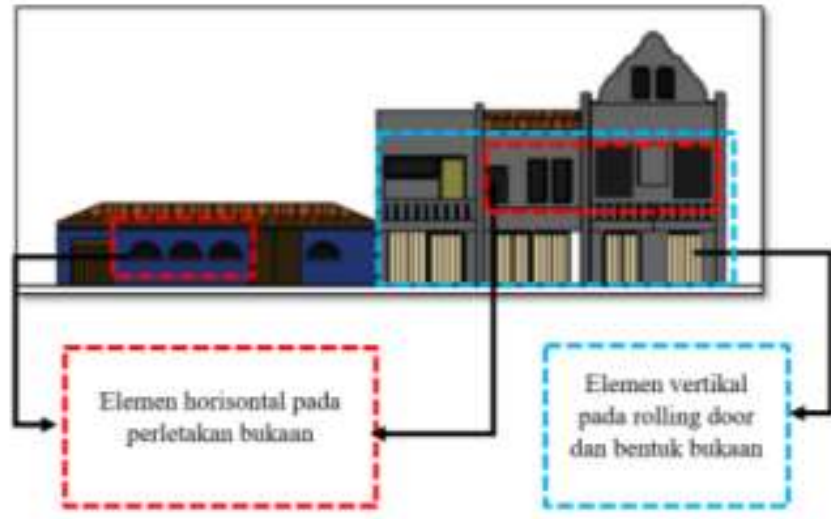

(c) Bentuk Bangunan Kawasan 1

Gambar 2. (a)Tampak Kawasan 1, (b),(c) Bentuk Bangunan Kawasan 1 Sumber: Digambar Ulang Peneliti, 2019

Hal yang dapat dilihat dari kontras dalam segi bentuk yaitu elemen pembentuk tampak bangunan dan bentuk atap. Pada bangunan Stasiun Tawang, Resort, Ruko 3, Bangunan Tua tidak berfungsi dan Ruko 5 elemen pembentuk tampaknya adalah elemen vertikal dan horisontal. Hal ini dapat dilihat pada garis-garis pembagi setiap lantai bangunan yang dibentuk secara horisontal. Selain itu juga terdapat elemen secara vertikal yang dapat dilihat dari garis-garis pembagi yang berupa kolom yang terlihat pada tampak bangunan. Hal ini, dapat dilihat bahwa bentuk bukaan menggunakan vertikal dan horisontal. Kontras dalam segi 
bentuk juga memperhatikan bentuk atap pada bangunan. Pada gambar terlihat bahwa semua bangunan menggunakan atap dak dan atap limasan. Hal ini membuat bangunan yang ada di tampak kawasan 1 kurang terlihat kekontras dalam segi bentuk.

Penerapan prinsip harmoni pada tampak kawasan 1 terlihat pada semua tampak bangunan yang ada. Pada tampak semua bangunan tersebut adanya elemen vertikal dan horizontal sebagai pembentuk tampak bangunan. Hal ini menjadikan tampak bangunan pada kawasan terlihat selaras karena keberagaman yang ada memberikan kesan keharmonian bentuk bangunan. Harmoni yang terlihat dari bentuk bangunan adalah pada bentuk jendela, rolling door, garis pembentuk tampak bangunan dan kolom bangunan. Hal ini menyebabkan pada tampak kawasan 1 adanya penerapan prinsip harmoni dalam segi bentuk.

2. Tampak Kawasan 2 (Jalan Sendowo)

a. Tampak Kawasan 2A

Pada tampak kawasan 2 area A (Gambar 3) terdapat bangunan ruko yang ditandai dengan kotak berwarna merah. Terdapat bangunan perkantoran yang ditandai dengan kotak berwarna hijau yaitu PT. Rumpun dan PT. Asuransi Tri Pakarta. Selain itu, terdapat rumah warga yang ditandai dengan kotak berwarna biru. Prinsip kontekstual bangunan yang ada pada tampak kawasan dua yaitu kontras dalam segi bentuk. Dapat dilihat pada gambar bahwa ketiga jenis bangunan yang ada memiliki bentuk yang berbeda.

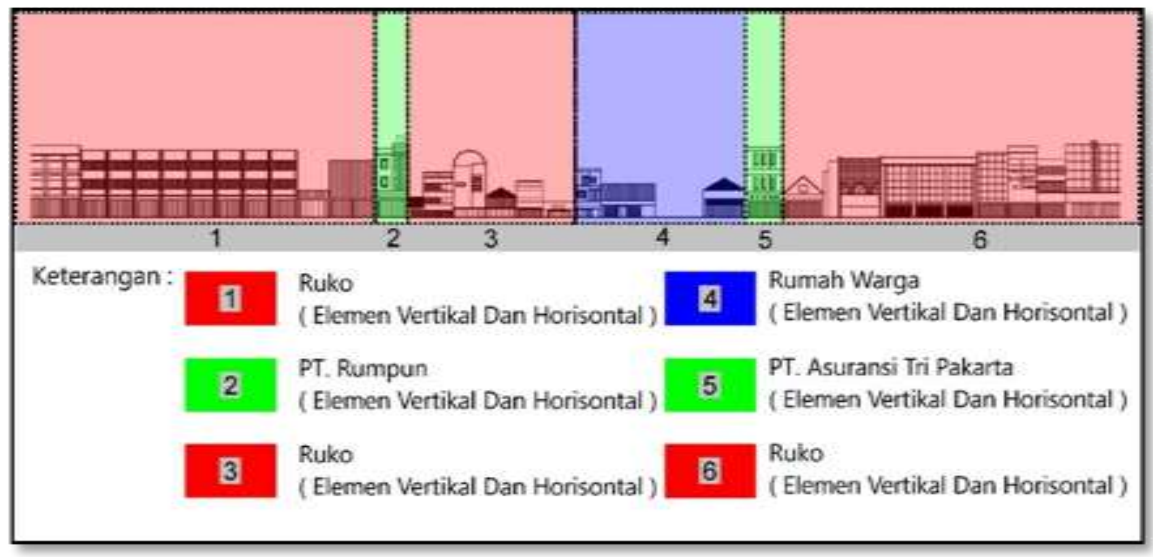

(a) Tampak Kawasan 2 Area A

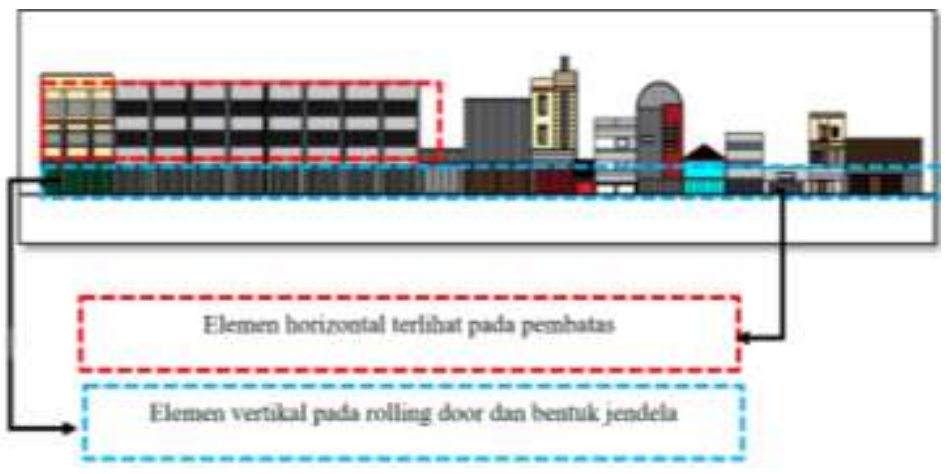

(b) Bentuk Bangunan Kawasan $2 A$ 


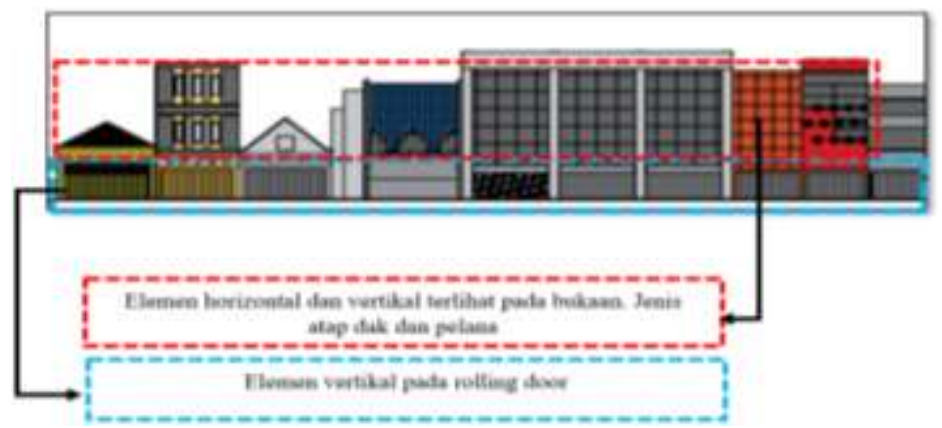

(c) Bentuk Bangunan Kawasan $2 A$

Gambar 3. (a) Tampak Kawasan 2 area A, (b),(c) Bentuk Bangunan Kawasan 2A Sumber: Digambar Ulang Peneliti, 2019

Hal yang dapat dilihat dari kontras dalam segi bentuk yaitu elemen pembentuk tampak bangunan dan bentuk atap. Pada bangunan Ruko 1, PT. Rumpun, ruko 3, rumah warga, PT. Asuransi Tri Pakarta dan ruko 6 memiliki elemen pembentuk tampak yaitu elemen vertikal dan horisontal. Hal ini dapat dilihat pada garis-garis pembagi setiap lantai bangunan yang dibentuk secara horisontal. Selain itu juga terdapat elemen secara vertikal yang dapat dilihat dari garis-garis pembagi yang berupa kolom yang terlihat pada tampak bangunan. Hal ini, dapat dilihat bahwa bentuk bukaan menggunakan vertikal dan horisontal. Kontras dalam segi bentuk juga memperhatikan bentuk atap pada bangunan. Pada gambar terlihat bahwa semua bangunan menggunakan atap dak, atap limasan dan atap pelana. Hal ini membuat bangunan yang ada di tampak kawasan 2A kurang terlihat kekontrasan dalam segi bentuk.

Penerapan prinsip harmoni pada tampak kawasan 2A terlihat pada semua tampak bangunan yang ada. Pada tampak semua bangunan tersebut tidak adanya suatu bangunan yang menggunakan elemen pembentuk tampak bangunan yang berbeda. Adanya elemen vertikal dan horisontal sebagai pembentuk tampak bangunan. Hal ini menjadikan tampak bangunan pada kawasan terlihat selaras karena keberagaman yang ada memberikan kesan keharmonian bentuk bangunan. Harmoni yang terlihat dari bentuk bangunan adalah pada bentuk jendela, rolling door, garis pembentuk tampak bangunan dan kolom bangunan. Hal ini menyebabkan pada tampak kawasan 2A adanya penerapan prinsip harmoni dalam segi bentuk.

b. Tampak Kawasan 2B

Pada tampak kawasan 2 area B (Gambar 4) terdapat beberapa ukuran pada bangunan ruko. Pada tampak kawasan 2B bangunan ruko ditandai dengan kotak berwarna merah yaitu, bangunan ruko di blok 1 - ruko blok 7. Prinsip kontekstual bangunan yang ada pada tampak kawasan 1 yaitu kontras dalam segi bentuk. Dapat dilihat pada gambar bahwa ketiga jenis bangunan yang ada memiliki bentuk yang berbeda. 


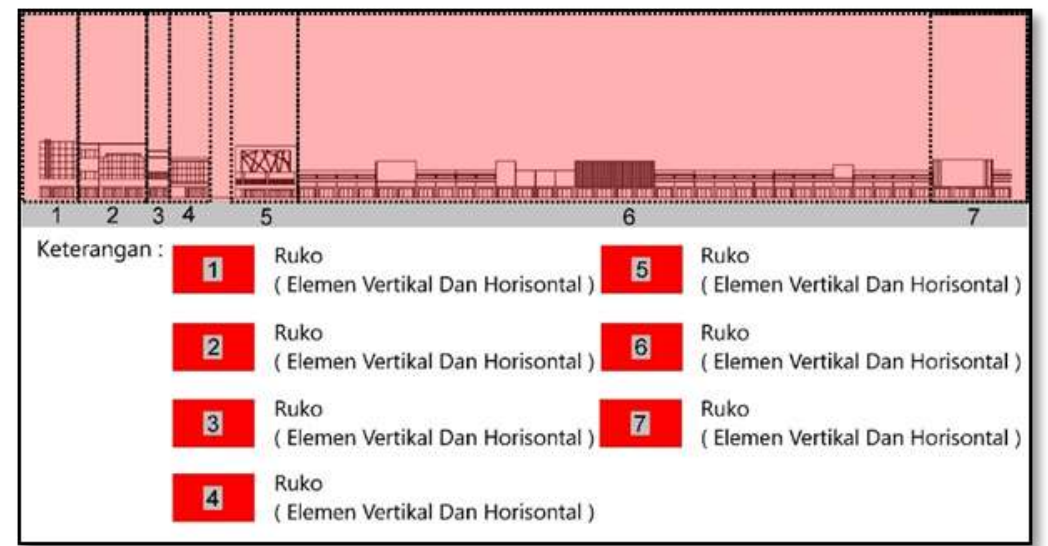

(a) Tampak Kawasn 2 Area B

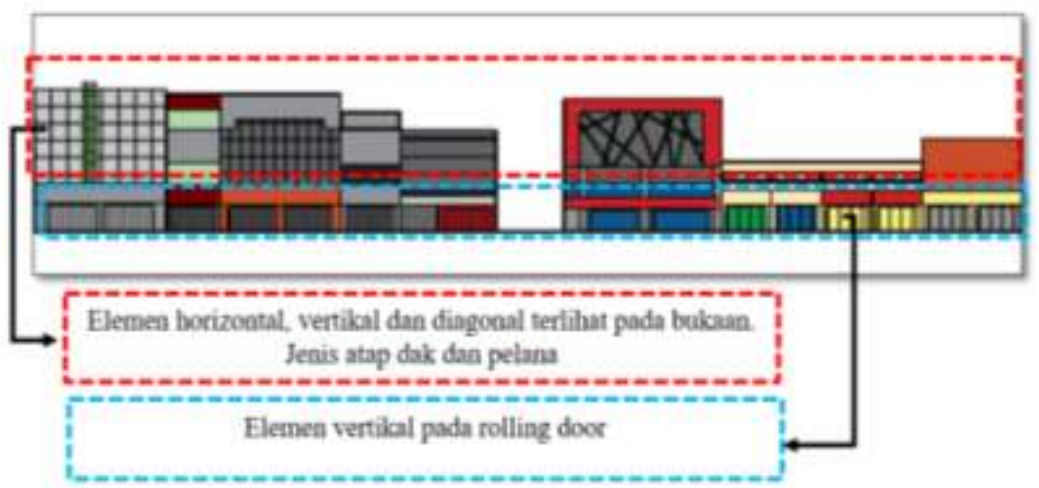

(b) Bentuk Bangunan Tampak Kawasan $2 B$

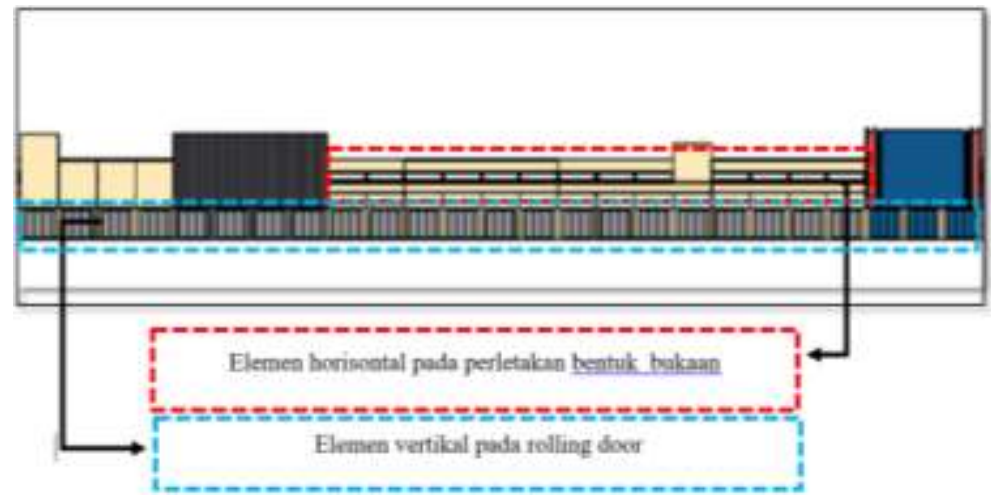

(c) Bentuk Bangunan Tampak Kawasan $2 B$

Gambar 4. (a) Tapmpak Kawasan 2 Area B, (b),(c) Bentuk Bangunan Tampak Kawasan 2B Sumber : Digambar Ulang Peneliti, 2019

Hal yang dapat dilihat dari kontras dalam segi bentuk yaitu elemen pembentuk tampak bangunan dan bentuk atap. Pada bangunan ruko 1, ruko 2, ruko 3, ruko 4, ruko 6 dan ruko 7 memiliki elemen pembentuk tampak yaitu elemen vertikal dan horisontal. Hal ini dapat dilihat pada garis - garis pembagi tiap lantai bangunan yang dibentuk secara horisontal. Selain itu juga terdapat elemen secara vertikal yang dapat dilihat dari garis - garis pembagi yang berupa kolom yang terlihat pada tampak bangunan. Hal ini, dapat dilihat bahwa bentuk bukaan menggunakan elemen vertikal dan horisontal. Pada tampak bangunan ruko 5 terlihat elemen 
campuran pada bentuk bukaan yaitu, elemen vertikal, horisontal dan diagonal. Hal ini membuat bangunan yang ada di tampak kawasan $2 \mathrm{~B}$ terlihat kontras dalam segi bentuk.

Penerapan prinsip harmoni pada tampak kawasan 2B terlihat pada semua tampak bangunan yang ada. Pada tampak semua bangunan tersebut tidak adanya suatu bangunan yang menggunakan elemen pembentuk tampak bangunan yang berbeda. Adanya elemen vertikal dan horisontal sebagai pembentuk tampak bangunan. Hal ini menjadikan tampak bangunan pada kawasan terlihat selaras karena keberagaman yang ada memberikan kesan keharmonian bentuk bangunan. Harmoni yang terlihat dari bentuk bangunan adalah pada bentuk jendela, rolling door, garis pembentuk tampak bangunan dan kolom bangunan. Hal ini menyebabkan pada tampak kawasan $2 \mathrm{~B}$ adanya penerapan prinsip harmoni dalam segi bentuk.

\section{Tampak Kawasan 3 ( Jalan Ronggowarsito )}

a. Tampak Kawasan 3A

Pada tampak kawasan 3A (Gambar 5) terdapat bangunan ruko yang ditandai dengan kotak berwarna merah. Terdapat bangunan fasilitas sosial atau bangunan umum yang ditandai dengan kotak berwarna kuning yaitu bangunan Aston Malang, bangunan gereja dan SD Marsudirin Gedangan. Selain itu, terdapat bangunan tua yang sudah tidak berfungsi yang ditandai dengan kotak berwarna hitam. Prinsip kontekstual bangunan yang ada pada tampak kawasan 3A yaitu kontras dalam segi bentuk. Dapat dilihat pada gambar bahwa ketiga jenis bangunan yang ada memiliki bentuk yang berbeda.

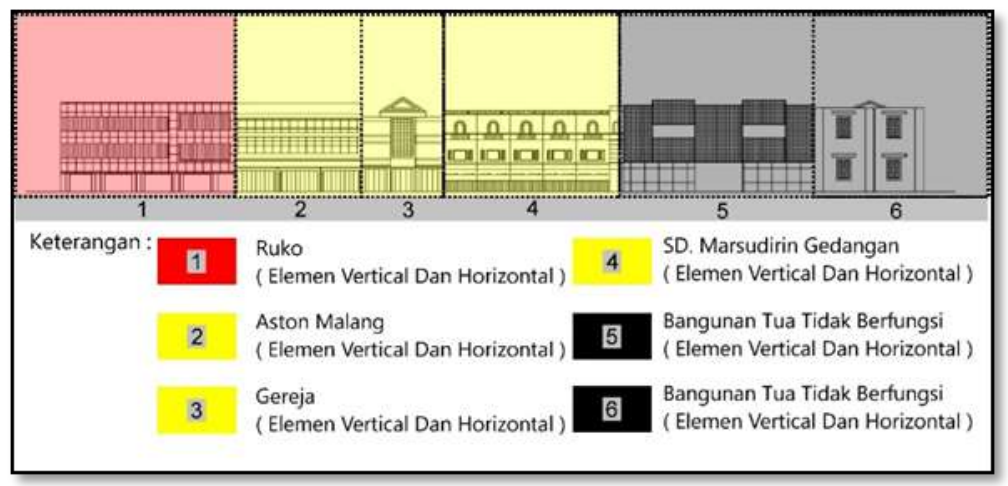

(a) Tampak Kawasan 3 Area A
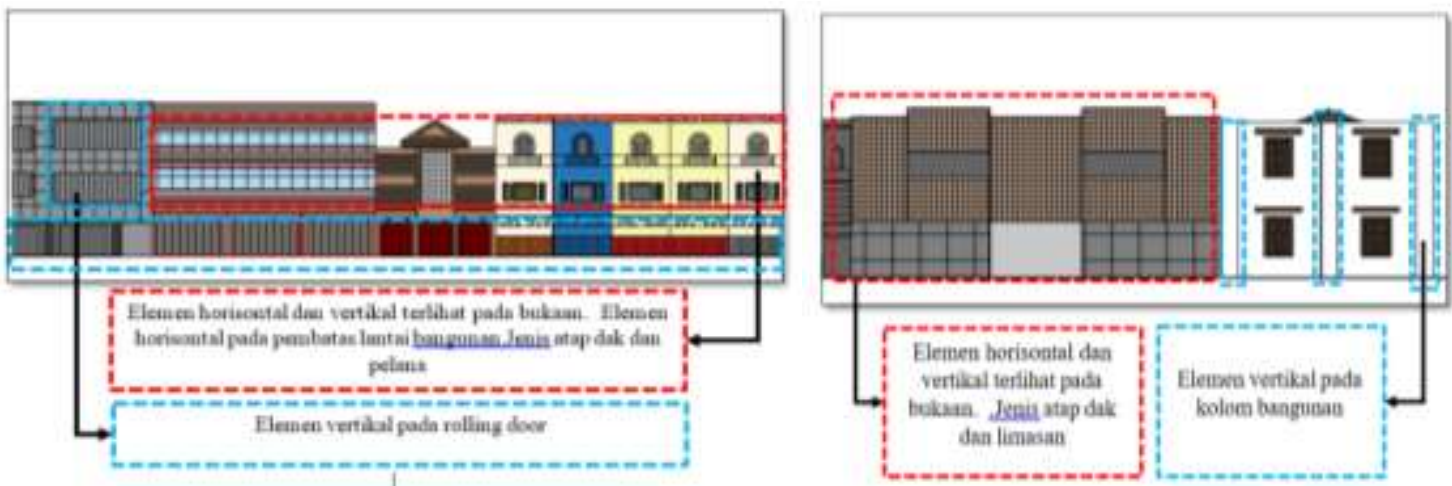

(b) Bentuk Bangunan Tampak Kawasan $3 A$

Gambar 5. (a) Tampak Kawasan 3 Area A, (b) Bentuk Bangunan Tampak Kawasan 3A Sumber: Digambar Ulang Peneliti, 2019 
Hal yang dapat dilihat dari kontras dalam segi bentuk yaitu elemen pembentuk tampak bangunan dan bentuk atap. Pada bangunan ruko 1, Aston Malang, Gereja, SD Marsudirin Gedangan, bangunan tua tidak berfungsi 5 dan bangunan tidak berfungsi 6 memiliki elemen pembentuk tampak yaitu elemen vertikal dan horisontal. Hal ini dapat dilihat pada garis - garis pembagi tiap lantai bangunan yang dibentuk secara horisontal. Selain itu juga terdapat elemen secara vertikal yang dapat dilihat dari garis - garis pembagi yang berupa kolom yang terlihat pada tampak bangunan. Hal ini, dapat dilihat bahwa bentuk bukaan menggunakan vertikal dan horisontal. Kontras dalam segi bentuk juga memperhatikan bentuk atap pada bangunan. Pada gambar terlihat bahwa pada bangunan menggunakan atap dak dana tap pelana. Pada tampak bangunan gereja terlihat bentuk atap yang berbeda dengan bangunan di sekitarnya. Hal ini membuat bangunan gereja yang ada di tampak kawasan 3A terlihat kontras dalam segi bentuk atap.

Penerapan prinsip harmoni pada tampak kawasan 3A terlihat pada semua tampak bangunan yang ada. Pada tampak semua bangunan tersebut tidak adanya suatu bangunan yang menggunakan elemen pembentuk tampak bangunan yang berbeda. Adanya elemen vertikal dan horisontal sebagai pembentuk tampak bangunan. Hal ini menjadikan tampak bangunan pada kawasan terlihat selaras karena keberagaman yang ada memberikan kesan keharmonian bentuk bangunan. Harmoni yang terlihat dari bentuk bangunan adalah pada bentuk jendela, rolling door, garis pembentuk tampak bangunan dan kolom bangunan. Hal ini menyebabkan pada tampak kawasan $3 \mathrm{~A}$ adanya penerapan prinsip harmoni dalam segi bentuk.

b. Tampak Kawasan 3B

Pada tampak kawasan 3 area B (Gambar 6) terdapat bangunan perkantoran yang ditandai dengan kotak berwarna hijau yaitu PT. Andika Teknik, bangunan rumah warga yang ditandai dengan kotak berwarna biru, dan bangunan tua yang sudah tidak berfungsi yang ditandai dengan kotak berwarna hitam. Prinsip kontekstual bangunan yang ada pada tampak kawasan 3B yaitu kontras dalam segi bentuk. Dapat dilihat pada gambar bahwa ketiga jenis bangunan yang ada memiliki bentuk yang berbeda.

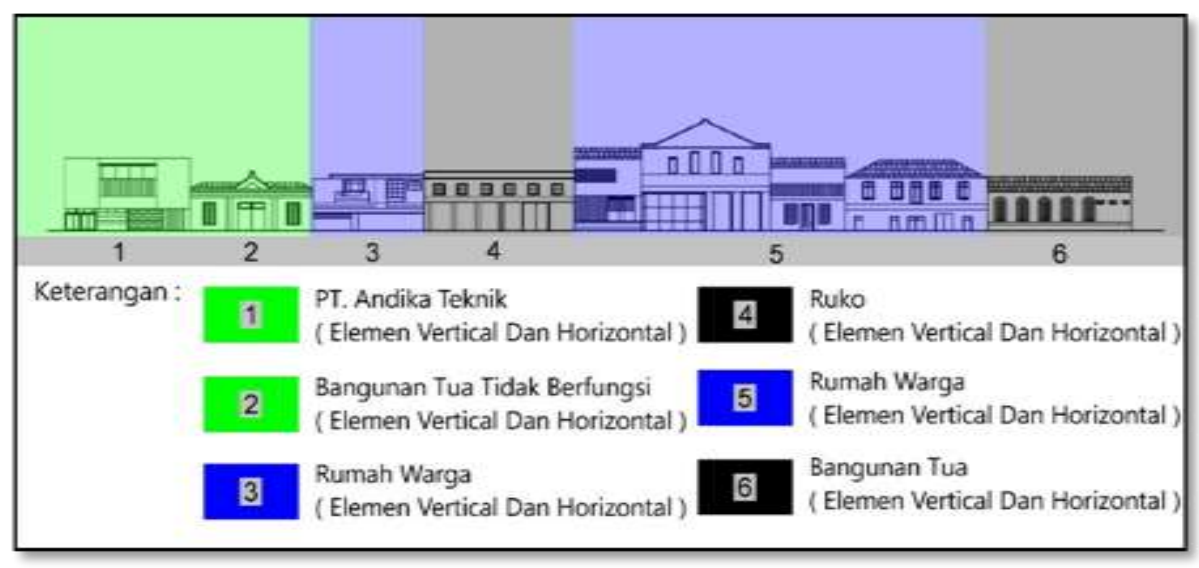

(a) Tampak Kawasan 3 Area B 


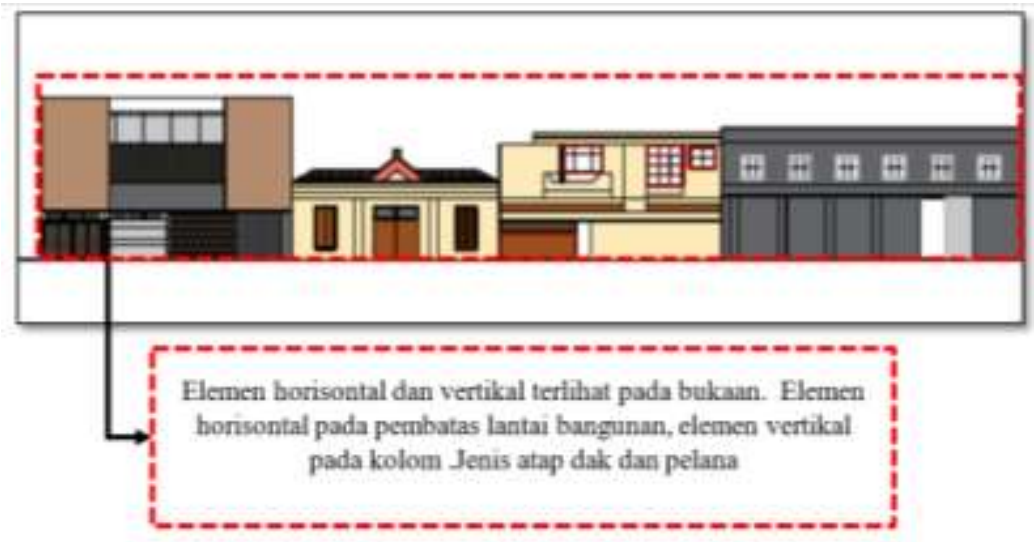

(b) Bentuk Bangunan Tampak Kawasan 3B

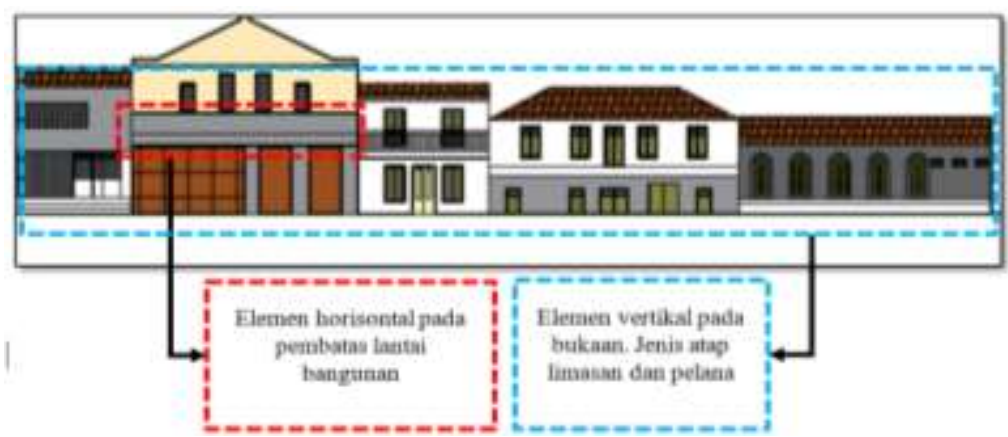

(c) Bentuk Bangunan Tampak Kawasan $3 B$

Gambar 6. (a) Tampak Kawasan 3 Area B,(b),(c) Bentuk Bangunan Tampak Kawasan 3B Sumber: Digambar Ulang Peneliti, 2019

Hal yang dapat dilihat dari kontras dalam segi bentuk yaitu elemen pembentuk tampak bangunan dan bentuk atap. Bangunan terdiri dari: (1) PT. Andika Teknik; (2) bangunan tua tidak berfungsi; (3) rumah warga; (4) rumah toko; (5) rumah warga; (6) bangunan tua memiliki elemen pembentuk tampak yaitu elemen vertikal dan horisontal. Hal ini dapat dilihat pada garis-garis pembagi setiap lantai bangunan yang dibentuk secara horisontal. Selain itu juga terdapat elemen secara vertikal yang dapat dilihat dari garis - garis pembagi yang berupa kolom yang terlihat pada tampak bangunan. Hal ini, dapat dilihat bahwa bentuk bukaan menggunakan vertikal dan horisontal. Kontras dalam segi bentuk juga memperhatikan bentuk atap pada bangunan. Pada gambar terlihat bahwa pada bangunan ada yang menggunakan atap dak, pelana dan limasan. Hal ini membuat bangunan yang ada di tampak kawasan 3B terlihat kontras dalam segi bentuk.

Penerapan prinsip harmoni pada tampak kawasan 3B terlihat pada semua tampak bangunan yang ada. Pada tampak semua bangunan tersebut tidak adanya suatu bangunan yang menggunakan elemen pembentuk tampak bangunan yang berbeda. Adanya elemen vertikal dan horisontal sebagai pembentuk tampak bangunan. Hal ini menjadikan tampak bangunan pada kawasan terlihat selaras karena keberagaman yang ada memberikan kesan keharmonian bentuk bangunan. Harmoni yang terlihat dari bentuk bangunan adalah pada bentuk jendela, rolling door, garis pembentuk tampak bangunan dan kolom bangunan. Hal ini menyebabkan pada tampak kawasan 3B adanya penerapan prinsip harmoni dalam segi bentuk. 


\section{Tampak Kawasan 4 (Bantaran Kali Semarang)}

Pada tampak kawasan 4 (Gambar 7) terdapat bangunan umum yang ditandai dengan kotak berwarna kuning yaitu bangunan cafe. Terdapat bangunan perkantoran yang ditandai dengan kotak berwarna hijau yaitu PT. Pelni, PT. Dharma Lautan Nusantara, Bank Mandiri KCP Semarang dan kantor Phapros. Prinsip kontekstual bangunan yang ada pada tampak kawasan 4 yaitu kontras dalam segi bentuk. Dapat dilihat pada Gambar 7, bahwa ketiga jenis bangunan yang ada memiliki bentuk yang berbeda.

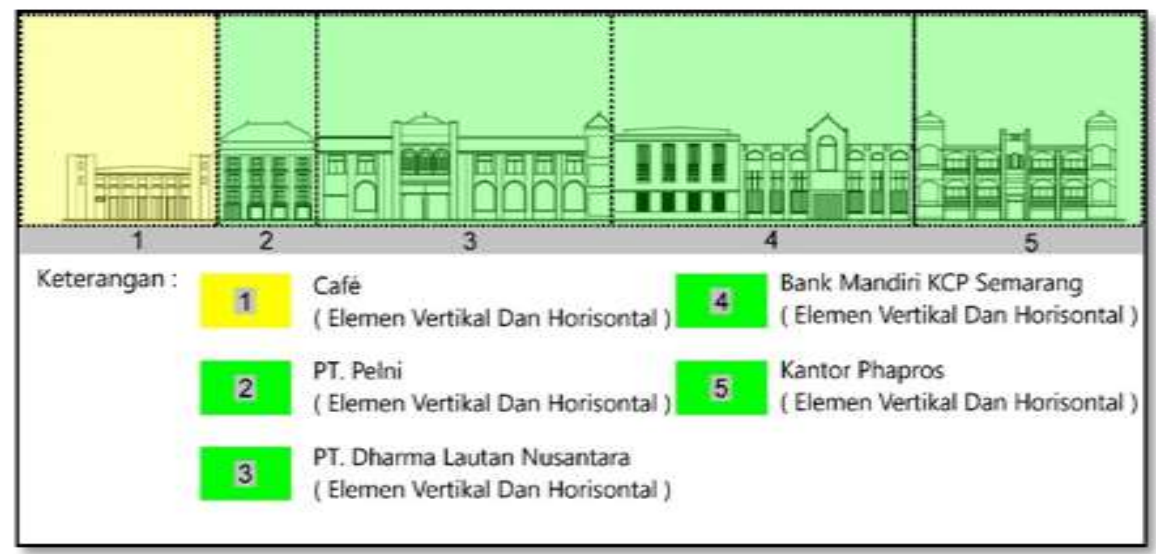

(a) Tampak Kawasan 4

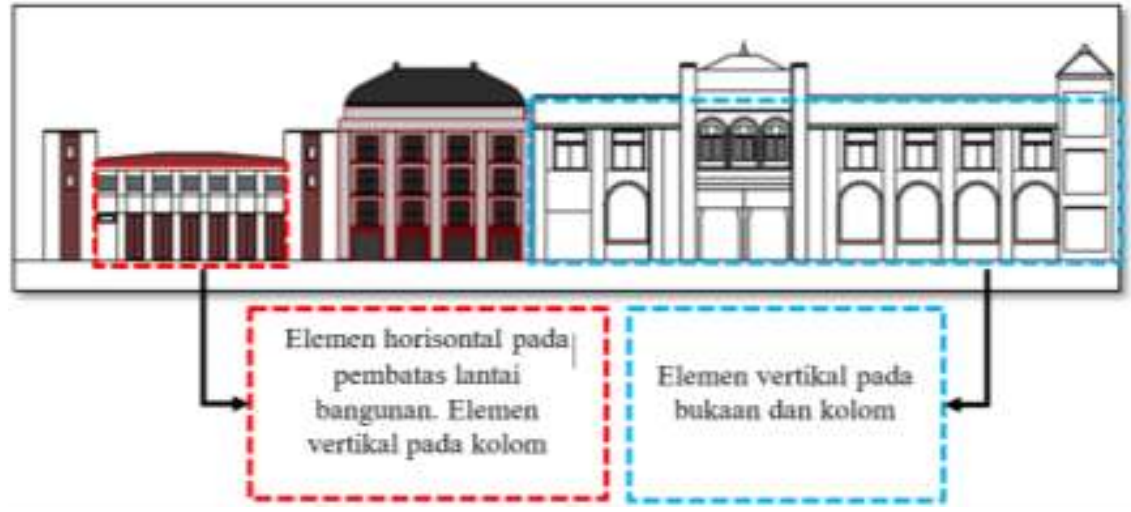

(b) Bentuk Bangunan Tampak Kawasan $3 B$

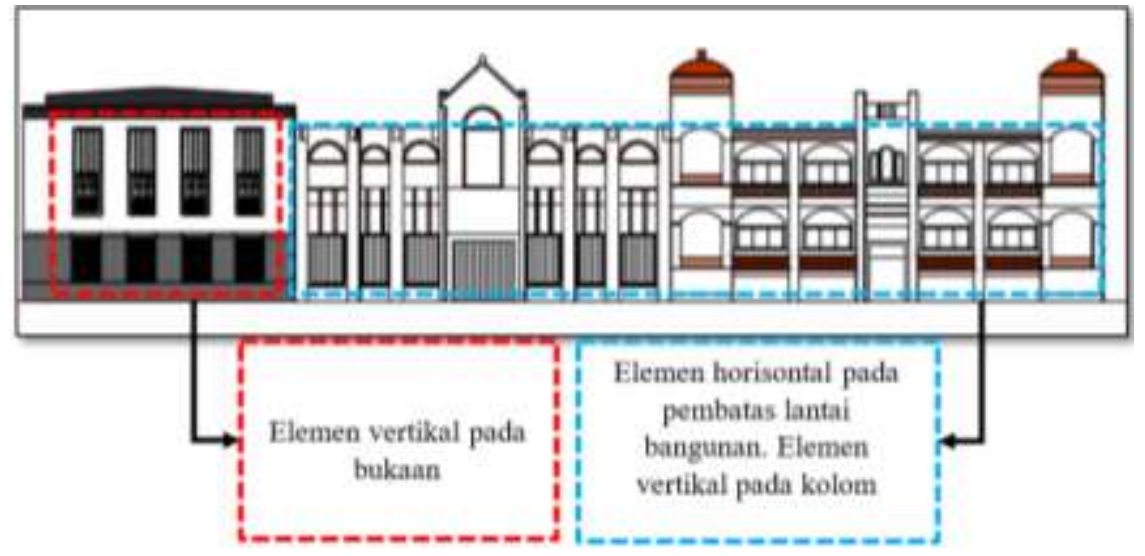

(c) Bentuk Bangunan Tampak Kawasan 3B

Gambar 7. (a) Tampak Kawasan, (b), (c) Bentuk Bangunan Tampak Kawasan 3B Sumber : Digambar Ulang Peneliti, 2019 
Hal yang dapat dilihat dari kontras dalam segi bentuk yaitu elemen pembentuk tampak bangunan dan bentuk atap. Pada bangunan café, PT. Pelni, PT. Dharma Lautan Nusantara, Bank Mandiri KCP Semarang dan Kantor Phapros memiliki elemen pembentuk tampak yaitu elemen vertikal dan horisontal. Hal ini dapat dilihat pada garis - garis pembagi tiap lantai bangunan yang dibentuk secara horisontal. Selain itu juga terdapat elemen secara vertikal yang dapat dilihat dari garis - garis pembagi yang berupa kolom yang terlihat pada tampak bangunan. Hal ini, dapat dilihat bahwa bentuk bukaan menggunakan elemen vertikal dan horisontal. Kontras dalam segi bentuk juga memperhatikan bentuk atap pada bangunan. Pada gambar terlihat bahwa pada bangunan menggunakan beragam jenis atap yang beragam, hal ini memperkuat bentuk bangunan pada tampak kawasan 4 yang merupakan bangunan yang bergaya Arsitektur Kolonial dan Eropa. Adanya keberagaman gaya arsitektur pada bangunan di kawasan 4 ini membuat bangunan yang ada terlihat kontras dalam segi bentuk.

Penerapan prinsip harmoni pada tampak kawasan 4 terlihat pada semua tampak bangunan dari segi penggunaan elemen pada tampak bangunan. Pada tampak semua bangunan tersebut tidak adanya suatu bangunan yang menggunakan elemen pembentuk tampak bangunan yang berbeda. Pembentuk tampak bangunan menggunakan elemen vertikal dan horisontal. Namun dari bentuk atap pada tampak bangunan kurang terlihat prinsip harmoni karena terdapat bentuk atap yang berbeda pada masing-masing bangunan Hal ini menjadikan tampak bangunan pada kawasan terlihat kurang menerapkan prinsip harmoni karena tidak adanya bentuk atap bangunan yang selaras.

\section{KESIMPULAN}

Arsitektur kontekstual dalam bentuk bangunan dilihat melalui prinsip kontras dan harmoni. Prinsip kontras menggambarkan adanya perbedaan bentuk bangunan yang mencolok dengan bangunan di sekitarnya. Prinsip harmoni menggambarkan bentuk bangunan yang selaras dengan bangunan lainnya. kontekstual bentuk bangunan dapat dilihat dari jenis atap dan penggunaan elemen pembentuk tampak bangunan yaitu, elemen vertikal dan horisontal.

Pada Kawasan Kota Lama Semarang penerapan kontras dalam segi bentuk tidak begitu terlihat karena pada semua bangunan yang ada memiliki bentuk yang hampir sama dengan bangunan di sekitarnya. Hal ini dikarenakan adanya gaya arsitektur kolonial yang melekat pada bangunanbangunan di Kawasan Kota Lama Semarang. Pada kawasan terlihat jelas penerapan prinsip harmoni pada bentuk bangunan yang ada. Pada bangunan memiliki beragam bentuk dan menggunakan berbagai jenis atap. Namun, adanya penggunaan elemen vertikal dan horisontal sebagai pembentuk tampak bangunan membuat bentuk bangunan terlihat selaras. Hal ini membuat kawasan Kota Lama Semarang terlihat menerapkan prinsip arsitektur kontekstual bentuk harmoni pada bangunan yang ada. Penerapan prinsip harmoni pada kawasan Kota Lama Semarang menambah nilai sejarah kawasan dan memperlihatkan adanya pelestarian nilai-nilai sejarah pada bangunan di Kawasan Kota Lama Semarang. 


\section{DAFTAR REFERENSI}

Aldilla Indira, Wiwik Setyaningsih, T. Y. I. (2018). Penerapan Arsitektur Kontekstual Pada Revitalisasi Stasiun. I(1), 37-44.

Eunike Trifena Kolibu, E. Al. (2017). Sekolah Tinggi Ilmu Kesehatan Bethesda Di Tomohon " Arsitektur Kontekstual ." 47-55.

Purwantiasning, AW.; Bahri, S. (2017). (2017). An Application Of Smart Building Concept For Historical Building Using Automatic Control System. Case Study: Fatahillah Museum. International Journal Of Built Environment And Scientific Research, 01(02), 115-122. Https://Doi.Org/Https://Doi.Org/10.24853/Ijbesr.1.2.115-122

Purwantiasning, AW; Bahri, S. (2019). Historical Attachment of Colonial Building Through Community Perception: Case Study of Museum Fatahillah, Kota Lama Jakarta. DOI: 10.21163/GT 2019.141.30. Journal Geographia Technica, Volume 14, Special Issue 2019, pp. 166-175. http://technicalgeography.org/index.php/specialissue-2019/275-18 purwantiasning

Purwantiasning, A. W., Masruroh, F., \& Nurhidayah. (2013). Analisa Kawasan Boat Quay Berdasarkan Teori Kevin Lynch. Nalars, 12(1), 59-72.

Rahayuningtyas. (2016). P Enerapan A Lgoritma C4 . 5 Pada A Nalisis ( S Tudi K Asus : Pt K Ayu L Apis A Sli M Urni ). (June 2015).

Vini Asfarilla, Yohannes Firzal, P. A. (N.D.). Perancangan Fakultas Kedokteran Gigi Universitas Riau Dengan Pendekatan Arsitektur Kontekstual. 1-9. 